\title{
Viral caracterisation of "zoonotic" Foamy viruses
}

\author{
Réjane Rua ${ }^{*}$ Edouard Betsem, Sara Calattini, Antoine Gessain \\ From 15th International Conference on Human Retroviruses: HTLV and Related Viruses \\ Leuven and Gembloux, Belgium. 5-8 June 2011
}

\section{Background}

Simian Foamy Virus is a widespread retrovirus infecting non-human primates (NHP). It is latent in PBMCs but replicates efficiently in saliva. It can be transmitted to humans mainly by bites, giving rise to a lifelong infection. Little is known about FV replication in humans. Genomic changes and quasi-species variability in human PBMCs and saliva have not been extensively studied yet.

\section{Materials and methods}

In South Cameroon, a series of hunters bitten either by an African Green Monkey (AGM), a chimpanzee (cpz) or a gorilla (ggo) were found to be SFV-infected. Viral isolation was performed by co-cultivation of their PBMCs with BHK cells. We also analyzed quasi-species (in a 425pb-Pol fragment) from PBMCs and saliva of 9 SFVggo-infected hunters.

\section{Results}

5 viral strains (1 SFVagm, 2 SFVcpz and 2 SFVggo) were isolated and sequenced. They are about 5-15\% divergent from the corresponding prototypical sequences. Their divergence is $\mathrm{s}(\mathrm{ub})$ pecies-specific and no common genomic feature was found between the "zoonotic" strains. Quasi-species variability ranges from $0,3 \%$ in saliva to $0,5 \%$ in PBMCs. In only $2 / 9$ cases, FV clones are clustered in two groups: PBMCs versus saliva.

\section{Conclusions}

In contrast with previous studies, no deletion or specific mutations have been observed in the 5 "zoonotic" FV, suggesting that FV restriction in humans is not due to genetically impaired viruses. Preliminary data indicate that quasi-species variability in saliva seems not higher

\footnotetext{
* Correspondence: rejane.rua@pasteur.fr

Epidemiology and Physiopathology of Oncogenic Retroviruses Unit, URA

CNRS 3015, Pasteur Institute, Paris, 75015, France
}

than in PBMCs, which might be explained by a low replication in human saliva.

Published: 6 June 2011

doi:10.1186/1742-4690-8-S1-A240

Cite this article as: Rua et al:: Viral caracterisation of "zoonotic" Foamy viruses. Retrovirology 2011 8(Suppl 1):A240.
Submit your next manuscript to BioMed Central and take full advantage of:

- Convenient online submission

- Thorough peer review

- No space constraints or color figure charges

- Immediate publication on acceptance

- Inclusion in PubMed, CAS, Scopus and Google Scholar

- Research which is freely available for redistribution

\section{() Biomed Central}

